\title{
Istraživanje mogućnosti primjene brnistre i njenih proizvoda na području srednje Dalmacije
}

\author{
Anita Pamuković \\ Veleučilište "Marko Marulić" u Kninu, Odjel Poljoprivreda krša, Hrvatska \\ e-mail:anita.pamukovic@veleknin.hr
}

\section{Boris Dorbić}

Veleučilište "Marko Marulić" u Kninu, Odjel Poljoprivreda krša, Hrvatska e-mail: boris.dorbic@veleknin.hr

\section{Marko Radeljak}

Sveučilište u Splitu, Odjel za stručne studije, Hrvatska e-mail: marko.radeljak@gmail.com

\begin{abstract}
SAŽETAK Brnistra (Spartium junceum L.) raste u zemljama Sredozemlja samo na područjima pored mora i na otocima. Brnistra se u Hrvatskoj danas koristi uglavnom kao ukrasna biljka, za suzbijanje erozije te u pčelarstvu. Početkom 20. stoljeća povećava se interes za brnistrom kao sirovinom. Intenzivnija proizvodnja u Hrvatskoj započinje 1919. godine za potrebe u tekstilnoj industriji. Godine 1967. prestaje se s njenom organiziranom proizvodnjom zbog pojave sintetičkih vlakana, koja su bila puno jeftinija. Postoje potencijali za proizvodnju mirisnih vodica, parfema, sapuna, aromatskih krema itd. Prije razvoja tržišta brnistre potrebno je educirati stanovništvo o biljci i gospodarenju njome. Inovativnost i originalnost trebali bi biti glavni faktori u brendiranju proizvoda od brnistre, uz istovremeno poštivanje njene povijesti i tradicije. Temeljem anketnog istraživanja učenika i studenata tijekom 2014. godine dobio se uvid o osrednjem znanju o mogućnostima uporabe brnistre (u ekosustavu za očuvanje bioraznolikosti, kao tekstilne sirovine, za dobivanje eteričnih ulja, kao ukrasnog bilja na degradiranim ruralnim krajobrazima i vrtovima) na području gradova Splita i Šibenika.
\end{abstract}

Ključne riječi: brnistra, brendiranje, sirovine, industrijsko bilje, krajobraz. 


\section{Uvod}

Brnistra (Spartium junceum L.) je samonikla grmolika biljna vrsta Sredozemlja koja raste pored mora i na otocima. Uspješno se razmnožava generativno (sjemenom) i vegetativno (sadnicama i reznicama). Na području Šibensko-kninske i Splitskodalmatinske županije ta se vrsta slabo koristi za hortikulturne namjene, iako je vrlo dekorativna te podnosi nepovoljne vremenske i okolišne uvjete (nedostatak vode, hranjiva itd.).

Od brnistre se dobiva izvrsno tekstilno vlakno u onim područjima gdje ne postoje uvjeti za sjetvu lana, konoplje i pamuka (Premužić, 1948.).

Slika 1.

Brnistra u cvatu

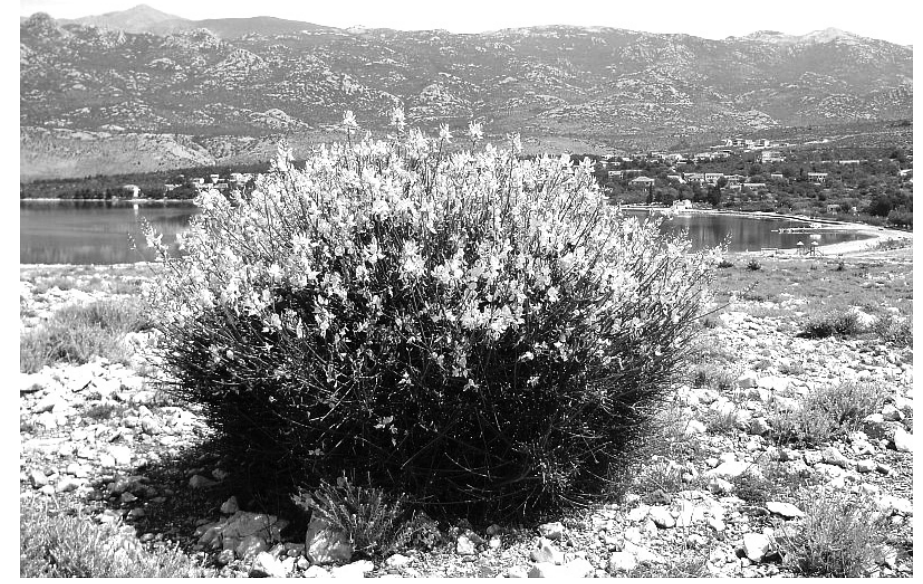

Izvor: http://www.zadarskilist.hr/clanci/09062012/nekad-se-brnistru-i-jelo-i-prelo

Brnistra cvate od sredine svibnja do kraja srpnja, ima grozdasti cvat sa žutim cvjetovima intenzivnog mirisa (slika 1.) (Hulina, 2011.). Plod joj je mahuna sa sjemenkama, koje u punoj zrelosti sadrže 9 - 10\% ulja. Vlakna brnistre dobivaju se biološkom maceVlakno brnistre otporno je na slatku i morsku vodu, žlavo je i praktički nepoderivo. Brnistrina se pređa od davnina koristila kao tekstilna sirovina. Uspoređujući brnistrinu pređu i istobrojnu suhu pređu lana, brnistrina je pređa jača za 36\%, a od vlažne lanene pređe za 17\%. Od suhe je konopljine pređe slabija 5\%, a od mokre konopljine pređe 42\% (Šatović, 1988.). Danas za brnistru postoji više narodnih imena, kao što su: brnestra, brnasta, bunestra, žukva, žuka, žuk, žutka, žutak i sl. (Šatović, 1988.). $\mathrm{Na}$ cijelom Mediteranu brnistra se kroz povijest koristila prvenstveno kao tekstilna kultura, međutim njena je primjena proširena, pa se tako koristila i kao medonosna kultura, krmna kultura te kao ljekovita biljka. Novija istraživanja navode brnistru kao vrlo dobru vrstu za stabilizaciju erozije tla (Pernar, 2010.; Preti i Giadrossich, 2009.; Chiatante i sur., 2003.; Scippa i sur., 2006.). Brnistra se tijekom povijesti, poslije otkrića 
Amerike, proširila i na ostale dijelove svijeta, kao što su sjeverna i južna Amerika, Azija i Australija, te je iz kultiviranog uzgoja prešla u samonikli oblik i kao takva je često invazivna korovna vrsta (Sanhueza i Zalba, 2012.; Mullin i sur., 2000.; Parker, Miller i Burrill, 1998.). Početkom 20. stoljeća povećava se interes za brnistru kao sirovinu za proizvodnju kompozitnih materijala. Intenzivnija proizvodnja u Hrvatskoj započinje 1919. godine za potrebe u tekstilnoj industriji te u rudarstvu, gdje se koristi kao remen za prijenos (zbog sporog truljenja). Ponovna proizvodnja brnistre na hrvatskom području započinje 1946. godine, kada se osim za potrebe tekstilne industrije koristi i u proizvodnji celuloze. Glavni razlog pokretanja proizvodnje brnistre vjerojatno je taj što je brnistra bila široko rasprostranjena, relativno dostupna te zbog pojave veće potražnje za tekstilom nakon 1945. god. Međutim istovremeno su se počeli koristiti i drugi tekstilni materijali, kao što su pamuk, juta, lan, konoplja i vuna, koji su tehnološki bili jeftiniji u proizvodnji. Godine 1967. prestaje se s njenom organiziranom proizvodnjom zbog pojave sintetičkih vlakana, koja su bila puno jeftinija. Tada se s tržišta brnistra gotovo izgubila, propale su lokalne poljoprivredne zadruge, a time i otkupne stanice za njenu preradu i prodaju. Ostali razlozi odustajanja od industrijskog iskorištavanja brnistre bili su troškovi koji se odnose na njeno branje, sakupljanje, prijevoz, rezidbu, gnojidbu te mala količina vlakana koja se dobivala nakon prerade. Bitno je navesti i činjenicu da je u nedostatku tehnologije i strukovne edukacije dalmatinska poljoprivreda bila zaostalija u odnosu na ostatak Hrvatske (Dorbić, Pamuković i Blažević, 2014.). U ponudu eko-poljoprivrednih gospodarstava na području Šibensko-kninske županije mogli bi se uključiti i različiti farmaceutski proizvodi od brnistre (kreme, sapuni, mirisne vodice i sl.). Postoje potencijali za proizvodnju mirisnih vodica, parfema, sapuna te aromatskih krema (Cerchiara i sur., 2010.). Prilikom istraživanja o mogućnostima koje nudi brnistra trebalo bi se voditi računa i o prethodnim iskustvima te je se ne bi trebalo isključivo tretirati kao tekstilnu sirovinu već i kao kulturu za primjenu u poljoprivredi, šumarstvu, prehrambenoj i farmaceutskoj industriji.

\section{Metodološke napomene}

U radu su se kao izvori sekundarnih podataka koristili arhivska građa, publikacije, znanstveni i stručni radovi. Kao izvor primarnih podataka korištena je metoda ispitivanja. Anketni upitnik sadržavao je pitanja otvorenog (19) i zatvorenog tipa (3). Za istraživanje je ciljano odabrana mlada populacija do 30 godina starosti, i to 34 maturanta Srednje strukovne škole u Šibeniku, usmjerenja Agroturistički tehničar (42,5\%) i 46 studenata Stručnog studija Trgovinsko poslovanje Sveučilišnog odjela za stručne studije Sveučilišta u Splitu (57,5\%). Odabir je ispitanika bio nasumičan. N je 80, od toga su 34 ispitanika s područja Šibenika i 46 ispitanika s područja Splita (52 žene i 28 muškaraca). Istraživanje je provedeno tijekom 2014. godine. Starosna struktura uzorka za Šibenik bila je: do 20 godina 33 ispitanika (97\%) i od 20 do 30 godina 1 ispitanik (3\%). Starosna struktura uzorka za Split bila je: do 20 godina 20 ispitanika (43,47\%) i od 20 do 30 godina 24 (56,53\%). Cilj anketnog istraživanja bio je dobiti na uvid znanja i stavove ispitanika o biljci brnistri i proizvodima od nje. Na temelju takvog uvida moguće je postaviti daljnje smjernice za tržište tih proizvoda. Za mjerenje znanja i stavova o biljci brnistri i proizvodima od nje korištene su grupa jednostavnih „Da/Ne“ pitanja te petostupanjska ljestvica (pri čemu su vrijednosti od 
1 do 5 označavale stupanj slaganja s ponuđenim odgovorom: 1 - uopće nije važna, 2 - nevažna, 3 - donekle važna, 4 - vrlo važna, 5 - iznimno važna).

Rezultati ankete obrađeni su u statističkom programu SPSS 6.0. za Windows sučelje.

\section{Pregled dosadašnjih istraživanja}

\subsection{Brnistra kroz povijest}

Brnistra se smatra autohtonom, samoniklom grmolikom vrstom koja na ovim prostorima raste od pamtivijeka. O brnistri se i danas govori s ljubavlju, njena berba i ritual prerade bili su dio težačkog prihoda u razdoblju oskudice nakon Drugog svjetskog rata. Budući da brnistra i danas prekriva obalu oko Splita, smatra se da su isejski Grci $^{1}$ nazvali to mjesto upravo prema brnistri. Grčki naziv za grad Split glasi Aspalathos, što u prijevodu znači žbunasta biljka (Kordić i Marasović-Alujević, 2009.). Na priobalnom i obalnom području mnoga su mjesta i lokaliteti sačuvali nazive upravo po toj biljci, npr. Žanestre pokraj Umaga, Brneštrovice kraj Cresa, Žukove na Braču, Žukova na Hvaru i Korčuli i sl. (Šatović, 1988.).

U prošlosti se brnistra najviše prela i tkala na području Šibenika i u crnogorskom primorju. Na šibenskom području moraju se istaknuti sljedeća mjesta: Zaton, Raslina, Jezera, Betina, Vodice, Pirovac itd., gdje se brnistra brala i prerađivala.

Za tekstilnu namjenu brnistru su najviše koristili siromašniji stanovnici koji nisu imali ovce od kojih se dobivala i vuna. Neki stanovnici otoka Murtera, primjerice, koristili su brnistru samo za izradu obuće, dok su Jezerani na istom otoku brnistrina vlakna češce koristili s vlaknima lana za izradu odjeće. U velikim se količinama brala i u Istri te u dubrovačkom primorju još za vrijeme prve i druge austrijske uprave 1797. - 1918., a između dvaju svjetskih ratova izvozila se u Italiju. Međutim sredinom 20. stoljeća dobivanje tekstilne sirovine od brnistre u Hrvatskoj se potpuno ugasilo. Ručno odvajanje vlakana iz grančica bio je dugotrajan posao te se navodi kao jedan od razloga napuštanja tog tradicionalnog zanata (Kovačević i sur., 2010.). Prema kazivanjima dionika iz vremena uporabe brnistre, odjeća od brnistre nije imala velika estetska obilježja. Od nje su se izrađivale čak i jakne, koje po kvaliteti nisu mogle konkurirati onima izrađenim od platna, kože i sl. Odjeća od brnistre koristila se uglavnom za rad u polju ili tvornici.

Brnistra se brala i obrađivala i na području Betine na Murteru te su od nje stanovnici pravili platno za vreće ili odjeću, kao što su npr. košulje i suknje seljaka (Čizmić i Vranješ-Šoljan, 2009.). Isto tako autori navode da je taj tradicionalni zanat stanovnika Betine zabilježio i opat Alberto Fortis u svojoj knjizi Put po Dalmaciji. Na otocima Kapriju i Kaknu, koji čine središnji dio šibenske otočne skupine, brnistra se nakon

$\mathbf{1}$ Isejski su Grci (doseljenici) u 3. stoljeću prije Krista osnovali Salonu. 
više dana namakanja u moru koristila za izradu grubog platna za prekrivače (Magaš, Faričić i Surić, 2003.). Na slici 2. prikazan je prekrivač za krevet iz sredine 20. stoljeća izrađen od vlakana brnistre koji potječe s otoka Paga. Brnistra osim tekstilne uloge nalazi i cijeli niz primjena u svakodnevnom životu pučanstva. Koristile su se njezine mladice za vezanje vinograda i voćnjaka, plele su se ograde, lijese za sušenje smoka$v^{2}$, cjedila za masline, plele su se košare i manje vrše, a od vlakana su se još pleli i konopčići za vezanje stoke i brodska užad. Suhe grančice brnistre lako planu, pa su se koristile i za potpaljivanje vatre. Osim što se koristila kao medonosna kultura, zbog lijepog i intenzivnog mirisa u srednjovjekovnoj Francuskoj od cvijeta se brnistre pravila mirisna vodica. Međutim brnistra se koristila i kao ljekovita biljka (Šatović, 1988.). Na slici 3. prikazane su vrše koje potječu s otoka Pašmana, izrađene 1952. godine.

Slika 2.

Prekrivač za krevet, predmet inventarnog broja XV/2043

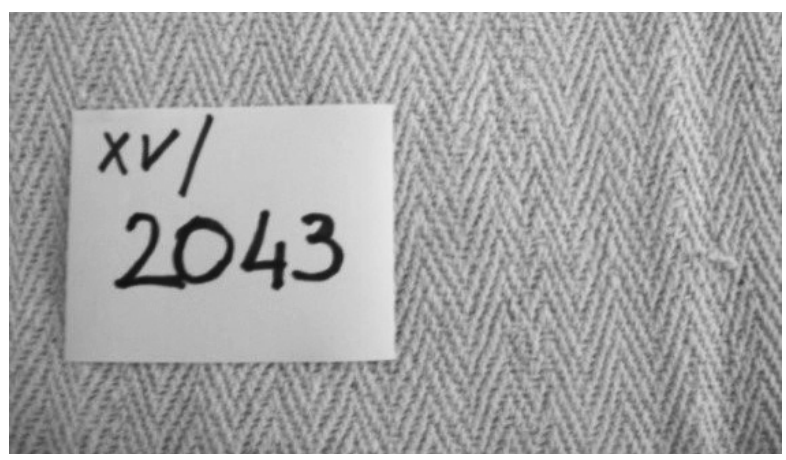

Slika 3.

Vrša, predmet inventarnog broja XI/28 i XI/27 (viša vrša)

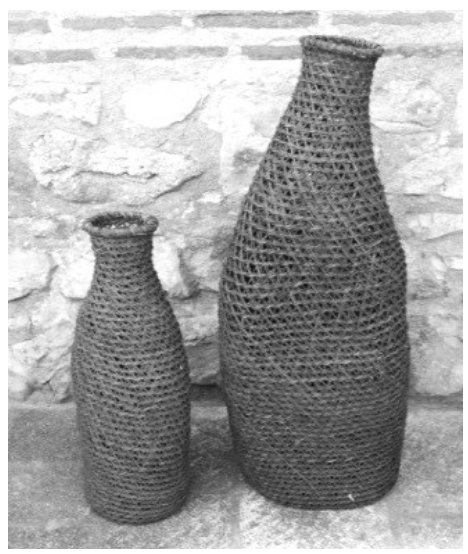

Izvor: fotografija, Etnografski muzej Split

2 U mjestu Raslini kod Šibenika tradicionalno se ispod i između drvenih okvira sušilice za smokve (tzv. granziole) umeću polusuhe stabljike brnistre na kojima se potom suše smokve (netom ubrane ili sumporane). 
Mediteranski pašnjaci uz more obiluju brnistrom, koja se odlikuje bujnim rastom i brzim širenjem. Njena vegetacijska masa prikladna je za ishranu ovaca, koza i kopitara.

Brnistra se u literaturnim izvorima navodi kao važna krmna kultura još početkom šezdesetih godina 19. stoljeća, koju su brstile ovce i koze u okolici Dubrovnika, na Cresu, Lošinju i u selima pod Biokovom (Šatović 1988.). Brnistra se brala za izrađivanje metli kojima su se mele gradske ulice Dubrovnika. Na šibenskom se području brnistra malo koristila za izradu metli, za tu su namjenu po selima uz more uglavnom koristili divlje forme sirka, koji su u narodu nazvali „metla“.

Tako se koristila duž cijele Dalmacije za metenje dvorišta, staja i ognjišta (Šatović, 1988.). Od nje su se izrađivale metle i u nekim europskim zemljama, pa su biljke koje su služile za izradu metli nazvane po državi ili regiji u kojoj su se koristile ili se i danas koriste. Tako je i brnistra dobila engleski naziv Spanish broom, španjolska metla (Nedelcheva, Dogan i Guarrera, 2007.).

\subsection{Brnistra u suvremenom razdoblju}

Ubrzanom industrijalizacijom nakon Drugog svjetskog rata te razvojem novih tehnologija moderni se čovjek sve više odmiče od prirode. Tek se u novijem modernom razdoblju budi svijest o potrebi očuvanja okoliša te različite ekološke inicijative postaju svojevrsni trend i dio svakodnevice suvremenog čovjeka. U današnje doba čovjek stalno pokušava osigurati svoj opstanak kroz različite vidove gospodarstva. Ekološka proizvodnja i uporaba zaboravljenih autohtonih biljaka jedan je od njih. U narednom tekstu prikazat ćemo vrijednosti brnistrine biljne sirovine. Kao što smo i prethodno naveli, brnistra je izvanredna tekstilna biljka od koje se mogu dobiti različiti proizvodi.

Premužić (1948.) te Oskar i Štiglmajer (1963.) navode da se vlakno brnistre može koristiti i za dobivanje celuloze, papira i nekih ljepljivih tvari. Gabriele i sur. (2010.) prezentirali su svoju patentiranu metodu ekstrakcije celuloznih vlakana iz brnistre. Metoda se bazira na kombinaciji kemijske faze (alkalne digestije) i fizikalno-kemijske faze, koja se sastoji od kompresije vrućim zrakom u autoklavu ${ }^{3}$ iza koje slijedi brza dekompresija. Tom se metodom dobivaju vlakna visoko kvalitetnih fizikalnokemijskih karakteristika, kao što su visoka mehanička otpornost i visok elasticitet, a proces traje nekoliko sati.

Brnistra pripada porodici Fabaceae, u koju spadaju različite zeljaste i drvenaste biljke. Neke od njih, kao i brnistra, u sjemenu sadrže i određenu količinu ulja (npr. soja).

3 Autoklav je uređaj za zagrijavanje tvari pod tlakom na temperaturu koja je viša od njihova vrelišta. 
Analiza fizikalno-kemijskih karakteristika pokazala je da je ulje sjemena brnistre nezasićeno, s visoko saponificirajućim i kiselim vrijednostima. Ulje sjemenki brnistre sadrži linolensku i palmitinsku kiselinu, većinom zasićene i nezasićene masne kiseline. Autori su zaključili da se ulje iz sjemena brnistre može koristiti za izradu sapuna, šampona za kosu i alkidnih smola (koje se koriste za boje na bazi umjetnih smola) (Cerchiara i sur., 2010.). Nadalje, analizom jednogodišnjih grančica brnistre utvrđen je visok sadržaj ekstraktivnih tvari koje bi se mogle primijeniti u industriji sapuna (Oskar i Štiglmajer, 1963.).

Brnistra raste na degradiranim krškim terenima, mlade biljčice podnose dugotrajnu ljetnu sušu, niče iz sjemena na vrlo oskudnom kamenitom tlu (Šatović, 1988.). Ispitivanjem vegetacije na opožarenim površinama pokazalo se da brnistra proklija već isto ljeto nakon požara (Ganatsas i sur., 2004.). Korijenje brnistre dobro veže tlo, a zbog kvržičnih bakterija obogaćuje tlo dušikom, tako da brnistra na siromašnom tlu može dati dobar prirod (Premužić, 1948.; Šatović, 1988.). Brnistra raste u velikim skupinama i svojim širokim habitusom usporava rast drugih biljaka. Zahvaljujući gustom pokrivanju tla brnistra se može koristiti radi kontrole hidroerozije. U suzbijanju erozije korijen brnistre ima značajan učinak. Korijen ima dobre biomehaničke karakteristike u kritičnim pedoklimatskim uvjetima, naročito na strmim terenima (Preti i Giadrossich, 2009.). Morfologija korijenovog sustava mladih sadnica brnistre znatno ovisi o nagibu terena (Chiatante i sur., 2003.; Scippa i sur., 2006.). Uočena je asimetrična distribucija bočnog korijenja oko glavnog korijena uz padinu i niz padinu terena. Pod utjecajem nagiba terena značajno se povećala duljina i broj korijenovih ogranaka. Podupiruća uloga glavnog korijena je ključna, međutim značajan rast bočnog korijenja ima velik značaj u učvršćivanju same biljke na nagnutom terenu (Chiatante i sur., 2003.; Scippa i sur., 2006.).

Brnistra se koristi u pošumljavanju i šumskim melioracijama na području Mediterana. Pokazala se vrlo uspješnom u sprječavanju erozije tla mediteranskog područja Hrvatske (slike 4. i 5.).

Topić (1995.) je usporedbom erozijskih procesa na goloj površini i površini pod šumskom vegetacijom na području sliva bujice Suvave došao do rezultata od 619,97 puta većeg gubitka tla na goloj površini nego pod vegetacijskim pokrivačem brnistre i šmrike, s udjelom od 90\% brnistre i 10\% šmrike. Podsijavanje brnistre i travne smjese pokazalo se uspješnim u suzbijanju erozije u Istri na lokalitetima Abrami i Butoniga (Pernar i sur., 2010.). U hortikulturnom smislu brnistra je interesantna biljka. Ima dekorativan habitus naročito stoga što grančice tokom godine ne gube zelenu boju, a cvate prekrasnim i mirisnim žutim grozdastim cvatovima. 
Slika 4.

Samonikla brnistra, okolica Trogira

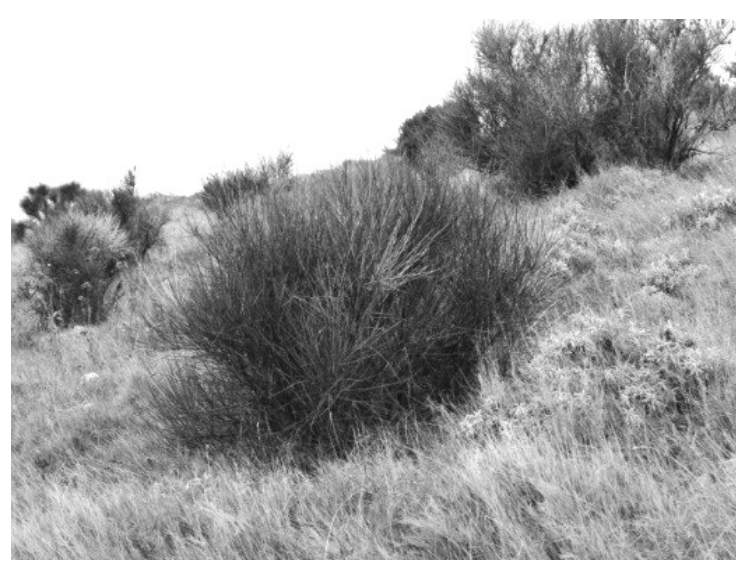

Slika 5.

Posađena brnistra uz prometnicu, Kaštel Sućurac

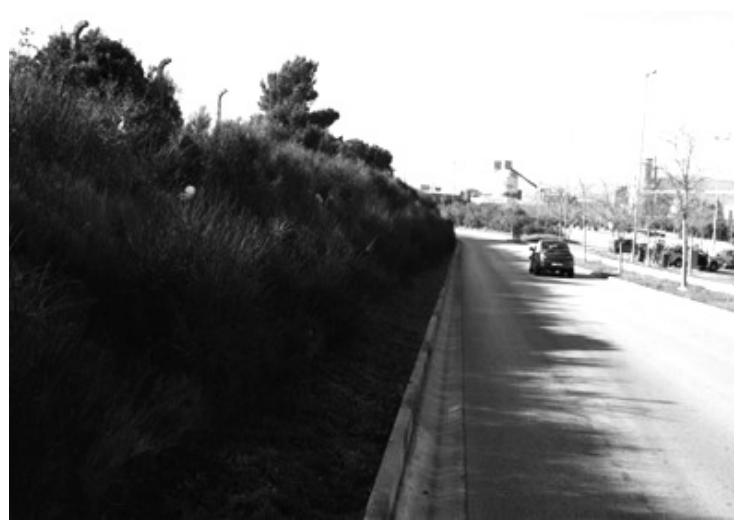

Brnistra je interesantna i kao medonosna kultura. Kao višegodišnja biljka spada među najvažnije medonosne biljke na kamenjarskim pašnjacima otoka Krka, Cresa i Paga (Britvec, Ljubičić i Šimunić, 2013.). Tafra, Pandža i Milović (2012.) istraživanjem su samoniklog i hortikulturnog (parkovnog) drveća i grmlja grada Omiša ukazali na dugogodišnje zanemarivanje domaćih biljnih vrsta u uzgoju. ${ }^{4}$

Za hortikulturne namjene brnistra se slabo koristi, osim kod uređenja većih vrtnih ili parkovnih površina. U parkovima i vrtovima može se uspješno koristiti kao pojedinačna vrsta, u različitim skupinama, kao živica, vrsta za suhe mediteranske kamenjare itd. Svojom dekorativnošću ne zaostaje za stranim vrstama u uzgoju. Svi su dijelovi biljke dekorativni (habitus, list, grančice, cvijet itd.).

${ }^{4}$ Autohtone (domaće) drvenaste vrste zbog svoje autentičnosti i bolje ekološke prilagodljivosti trebaju imati prednost u parkovnoj primjeni nad alohtonim (stranim) vrstama. 
U prijedlogu revitalizacije park-šume Komrčar na Rabu predložena je i brnistra kao ukrasni grm koji dobro podnosi sušu i posolicu te kao vrsta dobro razvijenog korijena (Španjol i Wolf, 1994.). Današnji izgled gradskog perivoja Roberta Visianija u gradu Šibeniku možemo zahvaliti rekonstrukciji povijesnog perivoja koji je nastao po uzoru na talijanske vrtove iz 19. stoljeća. Njegovom revitalizacijom 1996. godine, prema projektu perivojnog uređenja, uvrštene su nove biljne vrste, a među njima našla se i brnistra (Sironić, Sironić i Mornar, 2008.).

\subsection{Brnistra u svjetskom kontekstu}

Osim na području Mediterana brnistra se tijekom vremena i različitih svjetskih migracija proširila i na ostale kontinente.

Nakon otkrića Amerike brnistra je prenesena u ostale dijelove svijeta, gdje je odbjegla iz uzgoja (Planta Hortifuga) pa danas mjestimice predstavlja problem (Mullin i sur., 2000.). Analizom flore Urugvaja utvrđeno je da dio flore potječe iz europskog i mediteranskog područja te se tu našla i brnistra, koja je iz kulture prešla na spontani način razmnožavanja i širenja (Mérola i Raimondo, 2007.). Uvođenjem na argentinske pampase brnistra se mjestimice toliko proširila da je postala prijetnja ekosustavu tih travnjaka (Sanhueza i Zalba, 2012.). U SAD su se tijekom 20. stoljeća uvodile biljke koje su se kasnije proširile i postale ekonomski i ekološki važne invazivne korovne vrste. Brnistra kao jedna od takvih biljnih vrsta raširena je u zapadnim državama SAD-a (Mullin i sur., 2000.; Parker i sur., 1998.). U okviru istraživanja koje je provedeno u Australiji (Keatley i Hudson, 2007.) brnistra se našla među vrstama na kojima se pratilo vremensko pomicanje cvatnje s obzirom na promjenu klime u razdoblju od 1983. do 2006. godine.

Kroz povijest se brnistra koristila u narodnoj medicini, a njena se upotreba i danas zadržala u tradiciji zemalja gdje se koristila tijekom povijesti. U narodnoj medicini Turske cvjetovi brnistre koristili su se za liječenje peptičkog ulkusa (Yeşilada i sur., 2000.a; Yeşilada i sur., 2000.b). Aktivna tvar saponin spartitriozid izoliran je iz cvjetova brnistre i ima jaku antiulcerogenu aktivnost (Maleš i sur., 2005.). Iz cvjetova brnistre izoliran je saponin, oleanin koji također ima potencijalnu antiulcerogenu aktivnost (Yeşilada i Takaishi, 1999.). Sjeme brnistre koristilo se u obliku tinkture za liječenje vodene bolesti. U slučajevima korištenja više od dopuštene količine moglo je doći do povraćanja, pojačanog čišćenja crijeva i bubrežne iritacije (Maleš i sur., 2005.). Izolat spartein izoliran iz stabljike brnistre ima analeptički učinak na mišiće, skoparozid izoliran iz cvjetova brnistre djeluje diuretski (Maleš i sur., 2005.). U regiji Lucania na jugu Italije koristi se biljni sok brnistre u liječenju bradavica (Pieroni i Quave, 2005.). Bussman i Glenn (2011.) navode kako se u tradicionalnoj peruanskoj medicini koristi cijela biljka brnistre u liječenju artritisa i kostobolje.

Na području Dalmacije, za usporedbu s navedenim, nismo doznali da se brnistra ekstenzivno koristi u navedene svrhe. Za to bi trebalo sprovesti temeljita etnobotanička istraživanja. 


\subsection{Gospodarski potencijal brnistre u Hrvatskoj}

Brnistra se u Hrvatskoj danas koristi uglavnom kao ukrasna biljka, za suzbijanje erozije te u pčelarstvu, što više proizlazi iz spleta okolnosti nego određenog plana. Ako se uzme u obzir činjenica da je u svijetu prisutan zaokret prema prirodnom načinu života, shvatit ćemo neophodnost revitalizacije proizvodnje brnistre, budući da ona može predstavljati snažan ekonomski, turistički pa i socijalni kapital. Danas se prednost daje uzgoju pojedinih ljekovitih i aromatičnih biljaka čiji su biološki aktivni sastojci osnovne sirovine za proizvodnju mnogih lijekova, kozmetičkih pripravaka i aroma za prehrambene proizvode, u čemu bi brnistra mogla imati potencijala.

Prije razvoja tržišta brnistre potrebno je prvo educirati lokalno stanovništvo, naučiti ih kako što lakše prepoznati tu biljku, ispravno je sakupljati, čuvati i sušiti te kako gospodariti brnistrom na najprihvatljiviji način, uzimajući u obzir gospodarsku situaciju, poštivanje zakonske odredbe i kulturni identitet. Kao primjer edukacije o brnistri možemo navesti tematski tjedan brnistre u Gradskoj knjižnici Vodice, gdje su pripadnice KU-a Vodiške perlice govorile o primjeni brnistre kroz povijest u siromašnim domaćinstvima Vodica. Na slici 6. prikazana je izrada vijenca od brnistre u cvatu.

Slika 6.

Vijenac od brnistre

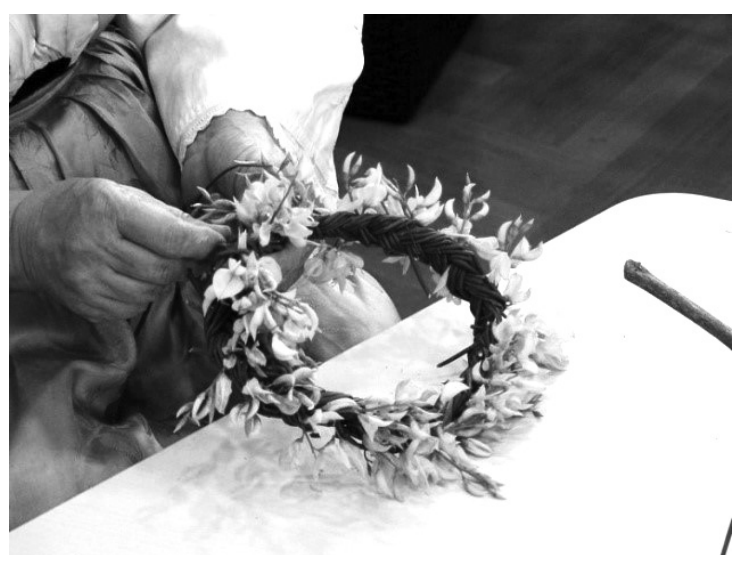

Izvor: Gradska knjižnica Vodice

Također, na tragu tog primjera možemo navesti knjigu o brnistri, From Weed to Fabric, Bischof i Kovačević (2013.). Knjiga je nastala u sklopu projekta „Revitalizacija tekstilne proizvodnje materijala iz brnistre - U susret hrvatskom autohtonom proizvodu: Od korova do tkanine“. Glavni cilj projekta bio je razvoj originalnog tekstilnog proizvoda izrađenog od brnistre kao autohtonog hrvatskog suvenira. Brojna istraživanja pokazuju da Hrvatska ima povoljne agroekološke uvjete za uzgoj brnistre. Danas se njenim uzgojem bavi tek nekoliko udruženja na razini EU-a kroz poticajne projekte radi očuvanja starih zanata (Kovačević i sur., 2010.). Izvorna upotreba brnistre može se naći u Petrčanima kraj Zadra. U Pirovcu kod Šibenika udruga 
Porart organizira tradicionalno branje i maceraciju brnistre (Katović i sur., 2011.). Na slikama 7. i 8. prikazane su ulice u Vodicama koje su okićene cvatućim grančicama brnistre za vrijeme procesije Velikog petka.

Slike 7. i 8.

Okićene ulice Vodica cvatućim grančicama brnistre
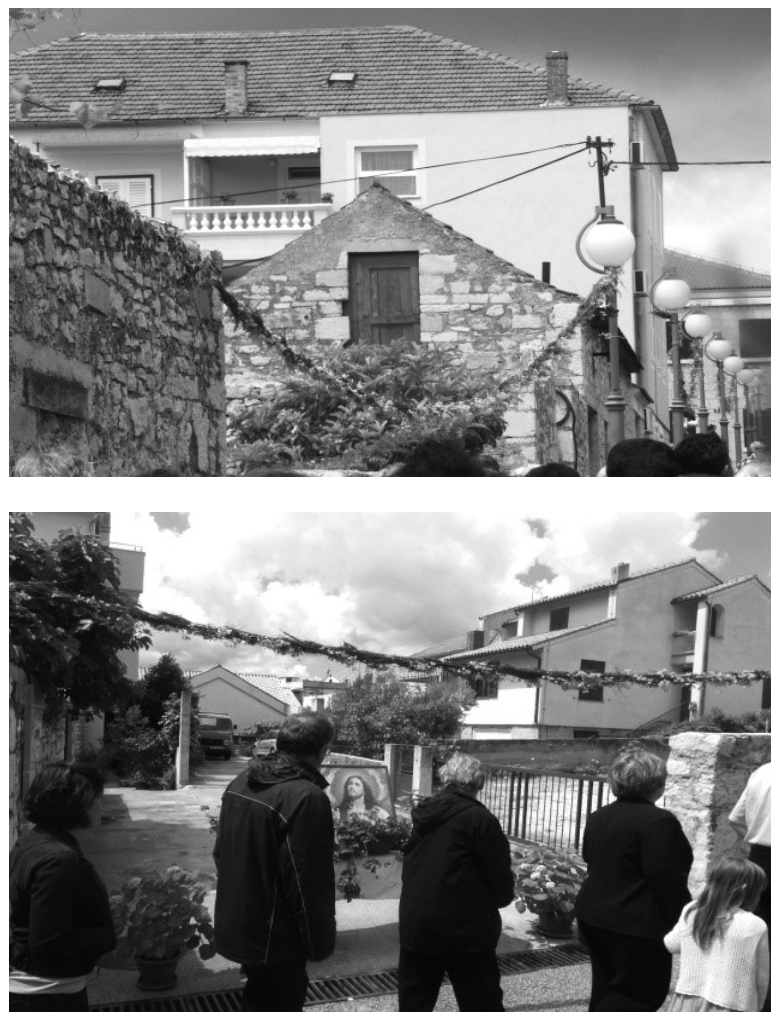

Da bi se tržište moglo potaknuti na korištenje proizvoda od brnistre, potrebno ga je prethodno istražiti te na temelju toga izraditi odgovarajuću promociju (promotivni splet) prema svim učesnicima u lancu proizvodnja - prodaja - potrošnja. U marketingu pojam „promocija“ označava motivaciju, odnosno poticanje potrošača na akciju. Domaće tržište ljekovitog i aromatičnog bilja još je uvijek u razvoju, stoga je potrebno prethodno raditi na informiranju i edukaciji proizvođača i potrošača o koristi od upotrebe proizvoda od brnistre (Barković, 1998.). Dakle, ukoliko želimo proizvoditi i prodavati proizvode od brnistre na tržištu, potrebno je razviti proces komunikacije $s$ tržištem. U današnjoj složenoj strukturi društva alati promocije služe nam za izgradnju komunikacije s potrošačima da bismo na taj način povećali vrijednost proizvoda te da bi se članovi ciljanog tržišta orijentirali prema tom proizvodu (Perreault i McCarthy, 2006.).

Kako bi se kupci na najbolji mogući način potaknuli na korištenje proizvoda od brnistre, potrebno je raditi na oglašavanju. Oglašavanje uključuje s jedne strane ma- 
sovne komunikacijske kanale, kao što su časopisi, radio, televizija i ostali masovni mediji ili direktnu komunikaciju poštom s druge. U tom bi se slučaju potrošače moglo informirati kroz radijske i TV emisije ili slanjem brošura direktno na adresu, distribucijom kroz novine ili specijalizirane časopise (Kesić, 2003.a). Unaprjeđenje prodaje usmjereno na potrošača moglo bi se ostvariti besplatnom podjelom uzoraka proizvoda od brnistre ili organiziranjem nagradne igre (Mihić, 2009.). Osobna prodaja komunikacija je određene osobe s drugom. Dakle prodavači bi trebali na prodajnom mjestu informirati potencijalne potrošače o koristima proizvoda od brnistre kroz različite demonstracije ili upute kako bi ih pokušali uvjeriti da kupe proizvode (Mihić, 2009.). Dakle prodaja brnistre mogla bi se odvijati kroz katalošku prodaju ili direktnu prodaju na štandovima, sajmovima ili stručnim seminarima (Dvorski i Dobrinić, 2002.).

Interaktivni ili internetski marketing omogućuje dvosmjerni protok informacija, pri čemu korisnici participiraju i modificiraju oblik i sadržaj informacija koje primaju i to trenutačno. Tu je potrebno da svaki proizvođač ima primjerenu internetsku stranicu s mogućnošću kupnje proizvoda, u ovom slučaju od brnistre, kao i prisutnost na društvenim mrežama, gdje bi se mogle dobiti sve potrebne informacije o proizvodu (Šerventić, 2008.). Odnosi s javnošću uspostavljaju i održavaju pozitivan imidž organizacije u javnosti. Stoga je za proizvođače proizvoda od brnistre važno stalno održavati prijateljske odnose sa širom javnošću kako bi na najbolji mogući način promovirali svoju djelatnost i upućivali na kvalitetu proizvoda (Kesić, 2003.b). Budući da proizvodi od brnistre već duže vrijeme nisu bili prisutni na tržištu, potrebno je pozorno pristupiti izradi promotivnog spleta, kao i njegovoj implementaciji. Razlog je za to zasićenost tržišta sličnim proizvodima ili imitacijama. Stoga bi inovativnost i originalnost trebali biti glavni čimbenici u promociji i brendiranju proizvoda od brnistre, uz istovremeno uvažavanje njezine povijest i tradicije (Barković, 1998.).

\section{Istraživanje percepcije učenika i studenata o brnistri i njenoj uporabi}

\subsection{Rezultati i rasprava}

Kako je u radu bilo neophodno istražiti stav stanovnika prema brnistri i proizvodima od nje, istraživanje je provedeno anketnim upitnikom na odabranom uzorku. Za istraživanje je ciljano odabrana mlada populacija do 30 godina starosti. $\mathrm{N}$ je 80 , od toga su 34 ispitanika s područja Šibenika i 46 ispitanika s područja Splita (52 žene i 28 muškaraca). Istraživanje je provedeno tijekom 2014. godine. Starosna struktura uzorka za Šibenik bila je: do 20 godina 33 ispitanika (97\%) i od 20 do 30 godina 1 (3\%). Starosna struktura uzorka za Split bila je: do 20 godina $20(43,47 \%)$ i od 20 do 30 godina 24 ispitanika (56,53\%). Rezultati dobiveni anketom obrađeni su statističkim metodama i prezentirani tabelarno. 
Tablica 1.

Percepcije ispitanika (Šibenik i Split) o poznavanju brnistre (u \%)

\begin{tabular}{|c|c|c|c|c|}
\hline & \multicolumn{2}{|c|}{$\begin{array}{l}\text { Odgovori ispitanika s } \\
\text { područja Splita }\end{array}$} & \multicolumn{2}{|c|}{$\begin{array}{l}\text { Odgovori ispitanika s } \\
\text { područja Šibenika }\end{array}$} \\
\hline Pitanje & $\begin{array}{c}\text { DA } \\
\underset{(\%)}{(\text { ukupno) }}\end{array}$ & $\begin{array}{l}\text { NE } \\
\text { (ukupno) } \\
(\%)\end{array}$ & $\begin{array}{c}\text { DA } \\
\text { (ukupno) } \\
(\%)\end{array}$ & $\begin{array}{l}\text { NE } \\
\text { (ukupno) } \\
(\%)\end{array}$ \\
\hline $\begin{array}{l}\text { 1. Jeste li do sada koristili proizvode od samoniklog } \\
\text { bilja u domaćinstvu? }\end{array}$ & 69,57 & 30,43 & 67,65 & 32,35 \\
\hline $\begin{array}{l}\text { 2. Jeste li samoniklo bilje koristili za dobivanje nekih } \\
\text { drugih proizvoda u domaćinstvu? }\end{array}$ & 47,8 & 52,17 & 47,06 & 52,94 \\
\hline $\begin{array}{l}\text { 3. Jeste li do sada čuli za biljku brnistru (Spartium } \\
\text { junceum L.) }\end{array}$ & 67,39 & 32,61 & 94,12 & 5,88 \\
\hline $\begin{array}{l}\text { 4. Jeste li znali da se brnistra može pronaći na } \\
\text { obalnim područjima i po otocima Mediterana? }\end{array}$ & 71,74 & 28,26 & 79,41 & 20,59 \\
\hline 5. Jeste li znali da je brnistra samonikla biljka? & 56,52 & 43,48 & 76,47 & 23,53 \\
\hline $\begin{array}{l}\text { 6. Jeste li znali da brnistra uspijeva na degradiranim } \\
\text { terenima i krškom kamenjaru? }\end{array}$ & 58,70 & 41,30 & 64,71 & 35,29 \\
\hline 7. Jeste li znali da je brnistra jako otporna na sušu? & 39,13 & 60,87 & 41,18 & 58,82 \\
\hline $\begin{array}{l}\text { 8. Jeste li znali da se brnistra lako razmnožava } \\
\text { sjemenom i sadnicama? }\end{array}$ & 15,22 & 84,78 & 17,65 & 82,35 \\
\hline $\begin{array}{l}\text { 9. Jeste li znali da za uzgoj biljke brnistre nije } \\
\text { potrebno obrađivati tlo? }\end{array}$ & 54,35 & 45,65 & 58,82 & 41,18 \\
\hline $\begin{array}{l}\text { 10. Jeste li znali da se brnistra može koristiti u } \\
\text { šumarskoj, hortikulturnoj i tekstilnoj proizvodnji te } \\
\text { u industriji? }\end{array}$ & 21,74 & 78,26 & 20,59 & 79,41 \\
\hline 11. Jeste li znali da je brnistra kvalitetnija od lana? & 10,87 & 89,13 & 25,88 & 94,12 \\
\hline
\end{tabular}


Tablica 2.

Percepcije ispitanika (Split i Šibenik) o biljci brnistri i njezinoj uporabi (Likert 1 - 5)

\begin{tabular}{|c|c|c|c|c|c|}
\hline & & \multicolumn{2}{|c|}{$\begin{array}{l}\text { Odgovori ispitanika s } \\
\text { područja Splita }\end{array}$} & \multicolumn{2}{|c|}{$\begin{array}{l}\text { Odgovori ispitanika s } \\
\text { područja Šbenika }\end{array}$} \\
\hline Pitanje & Ponuđeni odgovori & $\begin{array}{c}\text { Aritmetička } \\
\text { sredina }\end{array}$ & $\begin{array}{c}\text { Standardna } \\
\text { devijacija }\end{array}$ & $\begin{array}{c}\text { Aritmetička } \\
\text { sredina }\end{array}$ & $\begin{array}{c}\text { Standardna } \\
\text { devijacija }\end{array}$ \\
\hline \multirow{4}{*}{$\begin{array}{l}\text { 1. Uloga } \\
\text { brnistre u } \\
\text { ekosustavu je: }\end{array}$} & a) očuvanje bioraznolikosti & 3,76 & 1,353 & 3,00 & 1,393 \\
\hline & b) očuvanje tla od degradacije & 3,13 & 1,204 & 2,59 & 1,184 \\
\hline & c) sprječavanje erozije & 2,83 & 1,102 & 2,71 & 1,567 \\
\hline & d) očuvanje krajobraznog identiteta & 3,46 & 1,187 & 3,09 & 1,564 \\
\hline \multirow{4}{*}{$\begin{array}{l}\text { 2. Od brnistre } \\
\text { se može dobiti: }\end{array}$} & a) tekstil & 3,04 & 1,414 & 2,71 & 1,448 \\
\hline & b) briketi & 2,50 & 1,130 & 1,91 & 0,965 \\
\hline & c) ljepilo & 2,65 & 1,079 & 2,35 & 1,346 \\
\hline & d) žuti pigment & 2,89 & 1,286 & 2,88 & 1,431 \\
\hline \multirow{4}{*}{$\begin{array}{l}\text { 3. U } \\
\text { kozmetičkoj } \\
\text { industriji } \\
\text { brnistra se } \\
\text { može koristiti: }\end{array}$} & a) za dobivanje mirisa & 3,15 & 1,264 & 2,65 & 1,368 \\
\hline & b) za dobivanje eteričnih ulja & 3,35 & 1,233 & 3,35 & 1,574 \\
\hline & c) kao otapalo & 2,43 & 1,068 & 1,82 & 0,968 \\
\hline & d) kao gel za kosu & 2,35 & 1,119 & 1,91 & 0,996 \\
\hline \multirow{6}{*}{$\begin{array}{l}\text { 4. Kao } \\
\text { autohtoni } \\
\text { turistički } \\
\text { proizvod od } \\
\text { brnistre se } \\
\text { može dobiti: }\end{array}$} & a) vrša & 2,85 & 1,490 & 1,85 & 1,184 \\
\hline & b) košara & 3,07 & 1,482 & 2,73 & 1,639 \\
\hline & c) mirisno ulje & 3,46 & 1,206 & 2,88 & 1,472 \\
\hline & d) uže & 2,76 & 1,319 & 2,21 & 1,225 \\
\hline & e) tepih & 2,43 & 1,393 & 1,82 & 1,140 \\
\hline & f) cipele & 2,07 & 1,237 & 1,74 & 1,163 \\
\hline \multirow{5}{*}{$\begin{array}{l}\text { 5. Tradicionalna } \\
\text { uporaba } \\
\text { brnistre je: }\end{array}$} & a) za vezanje vinove loze & 2,85 & 1,264 & 1,76 & 1,129 \\
\hline & b) izrada tkanine & 3,09 & 1,297 & 2,32 & 1,342 \\
\hline & c) za proizvodnju rakija & 2,80 & 1,276 & 2,09 & 1,334 \\
\hline & d) kao ukrasna biljka & 3,46 & 1,149 & 2,65 & 1,574 \\
\hline & e) za proizvodnju užadi & 3,09 & 1,226 & 2,15 & 1,396 \\
\hline \multirow{4}{*}{$\begin{array}{l}\text { 6. Brnistra je } \\
\text { ukrasna biljka } \\
\text { zbog: }\end{array}$} & a) habitusa & 2,72 & 1,241 & 2,15 & 1,104 \\
\hline & b) lista & 2,89 & 1,251 & 2,29 & 1,192 \\
\hline & c) cvijeta & 3,65 & 1,449 & 3,76 & 1,597 \\
\hline & d) grančica & 2,89 & 1,286 & 2,76 & 1,208 \\
\hline \multirow{3}{*}{$\begin{array}{l}\text { 7. Kao ukrasna } \\
\text { biljka brnistra } \\
\text { je pogodna za } \\
\text { primjenu u: }\end{array}$} & a) vrtovima & 3,63 & 1,339 & 2,68 & 1,342 \\
\hline & b) gradskim parkovima i nasadima & 3,57 & 1,344 & 3,09 & 1,505 \\
\hline & c) degradiranim ruralnim krajobrazima & 3,78 & 1,153 & 3,15 & 1,635 \\
\hline \multirow{6}{*}{$\begin{array}{l}\text { 8. Na koji ste } \\
\text { način saznali za } \\
\text { biljku brnistru: }\end{array}$} & a) putem interneta & 1,87 & 1,293 & 1,97 & 1,467 \\
\hline & b) putem TV-a & 1,93 & 1,272 & 1,76 & 1,232 \\
\hline & c) putem stručnih časopisa & 1,93 & 1,143 & 1,74 & 1,189 \\
\hline & d) u vrtnom centru & 2,02 & 1,357 & 1,62 & 1,231 \\
\hline & e) putem razgovora & 3,04 & 1,632 & 3,09 & 1,782 \\
\hline & f) razno & 3,19 & 1,668 & 3,18 & 1,714 \\
\hline
\end{tabular}


Pregledom relevantne literature nije pronađeno slično istraživanje o biljci brnistri kroz anketni upitnik radi uvida u percepcije ispitanika o toj biljci i njezinoj uporabi. Anketnim upitnikom obuhvaćene su dvije skupine ispitanika različite dobi, različitog obrazovnog usmjerenja i različitog mjesta stanovanja: maturanti Srednje strukovne škole u Šibeniku, usmjerenja Agroturistički tehničar 34 (42,5\%) i studenti Stručnog studija Trgovinsko poslovanje Sveučilišnog odjela za stručne studije Sveučilišta u Splitu 46 (57,5\%). Cilj istraživanja bio je utvrditi u kojoj mjeri ispitanici poznaju brnistru te postoji li razlika u znanju o toj biljci s obzirom na razliku u dobi, obrazovanju i mjestu stanovanja. Prema tablici 1., obje skupine ispitanika koriste samoniklo bilje u svom domaćinstvu, što potvrđuje sličan postotak potvrdnih odgovora od 69,57\% ispitanika u Splitu i 67,65\% ispitanika u Šibeniku. Malo drugačiji rezultat pokazalo je pitanje o tome jesu li ispitanici čuli za brnistru. 67,39\% ispitanika u Splitu odgovorilo je potvrdno, dok je u Šibeniku potvrdno odgovorilo 94,12\% ispitanika. Razlog je tome možda činjenica što su ispitanici u Šibeniku bili učenici prirodoslovnog usmjerenja i što su stanovnici šibenskog područja. Kako je navedeno u literaturi, najviše su se stanovnici užeg šibenskog područja (Vodice, Pirovac, Murter, Jezera i Betina) u prošlosti bavili branjem i preradom brnistre (Kovačević i sur., 2010.; Čizmić i Vranješ-Šoljan, 2009.; Magaš i sur., 2003.). Nije bilo velikih odstupanja u potvrdnim odgovorima na pitanje o mediteranskom području kao mjestu rasta brnistre, preko $70 \%$ ispitanika u svakoj skupini odgovorilo je potvrdno. Na pitanje o tome je li brnistra otporna na sušu također su obje skupine ispitanika dale sličan odgovor, svaka oko 40\% potvrdno. Pitanje o brnistri kao biljci koja se lako razmnožava sjemenom i sadnicama također daje sličan rezultat, između 15\% i 18\% svake skupine odgovara potvrdno. Možemo reći da ispitanici iz obiju skupina, u Splitu i u Šibeniku, imaju znatno veće znanje o tome da je brnistra samonikla biljna vrsta Sredozemlja koja raste pored mora i na otocima, nego o njenim primarnim obilježjima, kao što su otpornost na sušu i način razmnožavanja, koja su manje općenita. Međutim pitanje je li brnistra samonikla biljka daje različite rezultate. 56,52\% ispitanika u Splitu odgovorilo je potvrdno, dok je u Šibeniku potvrdno odgovorilo 76,47\% ispitanika. Opet možemo veći postotak potvrdnog odgovora u Šibeniku pripisati činjenici da tu skupinu ispitanika čine učenici prirodoslovnog usmjerenja. U tablici 2. prikazani su rezultati ispitanika koji su pojedine odgovore ocjenjivali na petostupanjskoj ljestvici. Kod sastavljanja pitanja autori su se vodili dotadašnjim istraživanjima o brnistri (tablica 1. i tablica 2.). Međutim među pitanjima je navedeno i nekoliko odgovora o mogućnostima korištenja brnistre koje autori nisu pronašli u literaturi. Na skupinu pitanja o različitim mogućnostima korištenja brnistre ispitanici su najčešće davali odgovore prosječne vrijednosti. Slijedom toga smatramo kako postoji dobro temeljno znanje o toj biljci i njezinim proizvodima, koje bi u budućnosti olakšalo njezinu prezentaciju kroz različite edukacije. U literaturi se navodi korištenje brnistre za izradu tekstila (Premužić, 1948.; Kovačević i sur., 2010.; Čizmić i Vranješ-Šoljan, 2009.; Magaš i sur., 2003.) i ljepila (Premužić, 1948.; Oskar i Štiglmajer, 1963.). Na ponuđene odgovore da se brnistra koristi za izradu tekstila i ljepila ispitanici iz obiju skupina daju vrijednosti između 2,35 i 3,04. Nadalje, na ponudene odgovore da se brnistra koristi za izradu briketa i žutog pigmenta (nije pronađeno u literaturi), ispitanici iz obiju skupina navode vrijednosti između 1,91 i 2,89. Odgovorima u kojima se navode mogući turistički autohtoni proizvodi od brnistre (vrša, košara, mirisno ulje, uže, tepih i cipele) obje skupine ispitanika dodjeljuju vrijednosti od 1,74 do 
3,46. Ispitanici iz Splita dodijelili su najvišu vrijednost mirisnom ulju kao proizvodu od brnistre, dok su ispitanici iz Šibenika dodijelili najmanju vrijednost cipelama kao mogućem turističkom proizvod od brnistre. Cerchiara i sur. (2010.) navode da postoji potencijal proizvodnje mirisnih vodica, parfema, sapuna i aromatskih krema od brnistre. Kako je poznato iz literature, kroz povijest je brnistra služila za izradu različitih predmeta koji su se koristili u svakodnevnom životu (Etnografski muzej Split, 2015.; Kovačević i sur., 2010.; Šatović, 1988.). Ispitanici iz obiju skupina dodjeljuju prosječne vrijednosti (od 2,68 do 3,78) za ponuđene odgovore da se brnistra koristi kao ukrasna biljka u vrtovima, gradskim parkovima i nasadima te na degradiranim ruralnim krajobrazima. Sličnim istraživanjem Dorbić i sur. (2015.) dobili su malo veće vrijednosti. U istraživanju stavova o primjeni aromatičnih vrsta u vrtovima Drniša i okolice anketnim upitnikom ispitanici su ocjenjivali ukrasne karakteristike lavande, ružmarina, santoline, smilja, kadulje, vrijeska, matičnjaka i majčine dušice. Prosječne vrijednosti koje su ispitanici dodjeljivali ukrasnim karakteristikama pojedinih biljnih vrsta kreću se u rasponu od 3,74 do 4,43. Takav rezultat s većim prosječnim vrijednostima možda je opravdan time što su istraživane biljne vrste učestalije na ukrasnim zelenim površinama od brnistre. Također, ispitanici dodjeljuju srednje vrijednosti kod pitanja na koji su način saznali za brnistru. Dio ispitanika iz obiju skupina koji je saznao za tu biljku putem interneta, televizije, stručnih časopisa i u vrtnom centru daju vrijednosti do 2,02, dok ispitanici iz obiju skupina koji su saznali za brnistru putem neformalnog razgovora dodjeljuju veću vrijednost, do 3,09.

\section{Zaključak}

Autori predmetnog istraživanja temeljem dobivenih rezultata zaključuju da nema većih odstupanja u poznavanju brnistre između dvaju skupina ispitanika s obzirom na dob, obrazovno usmjerenje i različito mjesto stanovanja. Većina je ispitanika pokazala osrednje znanje kod većine pitanja o toj mediteranskoj biljci. Ipak, ispitanici sa šibenskog područja u većem su postotku odgovorili da poznaju ovu biljku (preko 90\%). Obje skupine ispitanika daju odgovore s preko $70 \%$ da je brnistra samonikla biljka i da raste na području Mediterana. Međutim pitanje o načinu razmnožavanja brnistre polučuje slabije rezultate. Do $20 \%$ ispitanika iz obiju skupina znalo je da se ova biljka lako razmnožava sjemenom i sadnicama. U prilog tome ide i činjenica da su ispitanici iz obiju skupina saznali za brnistru putem neformalnog razgovora $(3,09)$. To istraživanje, s obzirom na odgovore ispitanika, može dati smjernice na koji način educirati stanovništvo o toj biljci. U srednjim školama prirodoslovnog usmjerenja trebalo bi tu biljku prezentirati učenicima kroz stručnu literaturu ili kroz različite radionice. Vrtni centri, koji imaju veću ponudu različitog bilja, trebali bi poboljšati marketing brnistre različitim akcijama, npr. kroz „Dane brnistre“ kada bi se kupci mogli informirati o brnistri te kupiti sjeme ili sadnice po povoljnijim cijenama. S obzirom da značajan broj ispitanika poznaje navedenu vrstu, postoji potencijalno tržište brnistre, primjerice skupina ispitanika iz Splita dodjeljuje najvišu vrijednost za mirisno ulje kao potencijalni turistički proizvod od brnistre $(3,46)$. Prije razvoja tržišta brnistre potrebno je prvo educirati lokalno stanovništvo o tome kako što lakše prepoznati tu biljku, ispravno je sakupljati te ih naučiti kako gospodariti brnistrom na najprihvatljiviji način, uzimajući u obzir ekonomsku situaciju, poštivanje 
zakonske odredbe i kulturni identitet. Kod kreiranja različitih turističkih suvenira od brnistre inovativnost i originalnost trebali bi biti glavni faktori u brendiranju tih proizvoda. Osim toga, s obzirom na povijest i tradiciju, smatramo da se brnistru ne bi trebalo isključivo tretirati kao tekstilnu sirovinu već i kao kulturu za primjenu u poljoprivredi, šumarstvu, prehrambenoj i farmaceutskoj industriji.

\section{Literatura}

1. Barković, D. (1998). Analitika novog proizvoda. Osijek: Ekonomski fakultet Osijek.

2. Bischof, S. i Kovačević, Z. (2013). From weed to Fabric. Zagreb: Denona d. o. o.

3. Britvec, M.; Ljubičić, I. i Šimunić, R. (2013). Medonosno bilje kamenjarskih pašnjaka otoka Krka, Cresa i Paga. Agronomski glasnik, 1: 31-42.

4. Bussmann, R. W. and Glenn, A. (2011). Fighting pain: Traditional Peruvian remedies for thetreatment of Asthma, Rheumatism, Arthritis and sorebones. Indian Journal of Traditional Knowledge, 10 (3): 397-412.

5. Cerchiara, T.; Chidichimo, G.; Ragusa, M. I.; Belsito, E. L.; Liguori, A.; Arioli, A. (2010). Characterization and utilization of Spanish broom (Spartium junceum L.) seedoil. Industrial Cropsand Products, 31: 423-426.

6. Chiatante, D.; Sarnataro, M.; Fusco, S.; Dilorio, A.; Scippa, G. S. (2003). Modification of root morphological parameters and root architecture in seedlings of Fraxinus ornus L. and Spartium junceum L. growing on slopes. Plant biosystems, 137 (1): 47-56.

7. Čizmić, F. i Vranješ-Šoljan, B. (2009). Prve naznake demografske tranzicije: Stanovništvo Betine (1870.-1880.). Anali Zavoda za povijesne znanosti Hrvatske akademije znanosti i umjetnosti u Dubrovniku, 47: 143-169.

8. Dorbić, B., Karlo, T., Temim, E., Gugić, M., Friganović, E., Šarolić, M., Delić, Ž., Hadžiabulić, A. (2015). Istraživanje stavova o primjeni aromatičnih vrsta u vrtovima Drniša i okolice. Glasnik zaštite bilja, 6: 6-14.

9. Dorbić, B., Pamuković, A. i Blažević, M. (2014). Prilog poznavanju povijesti hortikulturne i bilinogojstvene edukacije stanovništva šibenskog kotara u razdoblju 1920.-1939. godine. Radovi Zavoda za povijesne znanosti HAZU u Zadru, 56: 263-287.

10. Dvorski, S. i Dobrinić, D. (2002). Direktni marketing. Varaždin: Fakultet organizacije i informatike Varaždin.

11. Etnografski muzej Split. (2015).

12. Gabriele, B.; Cerchiara, T.; Salerno, G.; Chidichimo, G.; Vetere, M. V.; Alampi, C.; Gallucci, M. C.; Conidi, C.; Cassano, A. (2010). A newphysical-chemical process for the efficient production of cellulose fibers from Spanish broom (Spartium junceum L.). Bioresource Technology, 101: 724-729.

13. Ganatsas, P. P.; Zagas, T. D.; Tsakaldimi, M. N.; Tsitsoni, T. K. (2004). Post fire regeneration dynamics in a Mediterranean type ecosystem in Sithonia, northern Greece: ten years after the fire. Proceedings 10th MEDECOS Conference. April 25-May 1. Rhodes. Greece. Pregledano 14. rujna 2016. (http://users.auth.gr/tsitsoni/files/eng/20.pdf.).

14. Gradska knjižnica Vodice. Pregledano 14. rujna 2016. (http://www.infovodice. com/kulturne-novosti/fotogalerija-ovotjedna-pricaonica-u-znaku-brnistre.html.). 
15. Hulina, N. (2011). Više biljke stablašice. Zagreb: Golden Marketing-Tehnička knjiga.

16. Katović, D.; Katović, A. i Krnčević, M. (2011). Spanish broom (Spartium junceum L.), U: Žiljak,V.; Tonković, S. i Kniewald, Z. (Ur.). Annual 2010/2011 of the Croatian Academy of Engineering. Zagreb: Intergrafika.

17. Keatley M. R. and Hudson, I. L. (2007). Shift In Flowering Dates Of Australian Plants Related To Climate: 1983-2006. 504-510. Pregledano 14. rujna 2016. (http://www.mssanz.org.au/MODSIM07/papers/9_s54/ShiftInFloweringDates s54 Keatley .pdf.)

18. Kesić, T. (2003 a). Integrirana marketinška komunikacija. Zagreb: Opinio.

19. Kesić, T. (2003 b). Ponašanje potrošača. Zagreb: Adeco.

20. Kordić, A. i Marasović-Alujević, M. (2009). Toponimi romanskoga porijekla na splitskom poluotoku. Školski vjesnik-časopis za pedagoška i školska pitanja, 57 (1-2): 91-126.

21. Kovačević, Z.; Krnčević, M.; Katović, A.; Katović, D. (2010). Brnistra-zaboravljena tekstilna sirovina. Tekstil, 59 (9): 410-421.

22. Magaš, D.; Faričić, J. i Surić, M. (2003). Prirodno-geografske odrednice razvitka otoka Kaprija, Kakna i pripadajućih otočića. Geoadria, 8 (2): 45-66.

23. Maleš, Ž.; Plazibat, M.; Bilušić Vundać, V.; Kremer, D.; Alar, J. (2005). Istraživanje flavonoida i aminokiselina brnistre - Spartium junceum L. (Fabaceae). Farmaceutski glasnik: glasilo hrvatskog farmaceutskog društva, 61: 499-509.

24. Mérola, S. and Raimondo, F. M. (2007). European and Mediterranean plants in the wild flora of Uruguay. Bocconea, 21: 391-404.

25. Mihić, M. (2009). Upravljanje osobnom prodajom. Split: Ekonomski fakultet Split.

26. Mullin, B. H.; Anderson, L. W.; Di Tomaso, J. M.; Eplee, R. E.; Getsinger, K. D. (2000). Invasive plant species. Cast. Council for agricultural science and technology. 13. Pregledano 14. rujna 2016. (http://www.cast-science.org/download.cfm ?PublicationID=2864\&File=f030a5f2afb66480223c4b233e6767307816.).

27. Nedelcheva, A. M.; Dogan, Y. and Guarrera, P. M. (2007). Plants traditionally used to make brooms in several European countries. Journal of Ethnobiology and Ethnomedicine, 3:20. Pregledano 14. rujna 2016. (https://ethnobiomed.biomedcentral.com/articles/10.1186/1746-4269-3-20.).

28. Oskar, G. i Štiglmajer, G. (1963). Brnistra kao sirovina za celulozu. Šumarski list, (87): 347-353.

29. Parker, B.; Miller, G. and Burrill, L. C. (1998). Scotch Broom Cytisus Scoparius L. Link. Weeds. A Pacific North west Exstension Publication. Oregon. Idaho. Washington. PNW 103.

30. Perreault, W. D. and McCarthy, E. J. (2006). Essentials of marketing. Boston: McGraw-Hill/Irvin.

31. Pernar, N.; Bakšić, D.; Perković, I.; Holjević, D. (2010). Odraz sanacije erodiranog terena na svojstva tla na flišu - slučajevi Abrami i Butoniga u Istri. Šumarski list, (5-6): 229-239.

32. Pieroni, A. and Quave, C. L. (2005). Traditional pharmacopoeias and medicines among Albanians and Italians in southern Italy: A comparison. Journal of Ethnopharmacology, 101: 258-270.

33. Premužić, A. (1948). Planski uzgoj brnistre na našem primorskom kršu. Šumarski list, 11 (72): 364-371. 
34. Preti, F. i Giadrossich, F. (2009). Root rein forcement and slope bioengineering stabilization by Spanish Broom (Spartium junceum L.). Hydrology and Earth System Sciences Discussions, 6: 3993-4033.

35. Sanhueza, C. and Zalba, S. M. (2012). Experimental control of Spanish broom (Spartium junceum) invading natural grasslands. Management of Biological Invasions, 3 (2): 97-104.

36. Scippa, G. S.; DiMichele, M.; DiIorio, A.; Costa, A.; Lasserre, B.; Chiatante, D. (2006). The response of Spartium junceum Roots to Slope: Anchorageand Gene Factors. Annals of Botany, 97: 857-866.

37. Sironić, M.; Sironić, D. i Mornar, N. (2008). Gradski perivoj u Šibeniku. Metode i rezultati rekonstrukcije u 20. stoljeću. Prostor, 1 (35): 126-141.

38. Šatović, F. (1988). Brnistra (Spartium junceum L.) celulozno vlaknata mediteranska biljka. Poljoprivreda $i$ šumarstvo, XXXIV (2-3): 61-77.

39. Šerventić, S. (2008). Utjecaj marketinške komunikacije na pribvaćanje novog proizvoda. Split: Ekonomski fakultet Split.

40. Šimunović, P. (1975). Ogled jezičnih osobina bračke čakavštine. Narodna umjetnost: hrvatski časopis za etnologiju i folkloristiku, 11/12 (1): 497-517.

41. Španjol, Ž. i Wolf, S. (1994). Biološko-ekološka i prostorna valorizacija parkšume "Komrčar" na Rabu. Šumarski list, CXVIII (5-6): 153-166.

42. Tafra, D.; Pandža, M. i Milović, M. (2012). Dendoflora Omiša. Šumarski list, 1112: 605-617.

43. Topić, V. (1995). Utjecaj šumske vegetacije na suzbijanje erozije u bujičnim slivovima mediteranskog područja Hrvatske. Šumarski list, 9-10: 299-303.

44. Zadarski list. Magazin. Pregledano 14. rujna 2016. (http://www.zadarskilist.hr/ clanci/09062012/nekad-se-brnistru-i-jelo-i-prelo.).

45. Yeşilada, E. i Takaishi, Y. (1999). A saponin with anti-ulcerogenic effect from the flowers of Spartium junceum. Phytochemistry, 51: 903-908.

46. Yeşilada, E.; Takaishi, Y.; Fujita, T.; Sezik, E. (2000 a). Anti-ulcerogenic effects of Spartium junceum flowers on in vivo test models in rats. Journal of Ethnopharmacology, 70: 219-226.

47. Yeşilada, E.; Tsuchiya, K.; Takaishi, Y.; Kawazoe, K. (2000 b). Isolation and characterization of free radicals cavenging flavonoid glycosides from the flowers of Spartium junceum by activity-guided fractionation. Journal of Ethno pharmacology, 73: 471-478. 
Prethodno priopćenje

\title{
Anita Pamuković
}

University of Applied Sciences "Marko Marulić" in Knin, Department of agriculture karst, Croatia e-mail:apamukovic@veleknin.hr

\section{Boris Dorbić}

University of Applied Sciences "Marko Marulić" in Knin, Department of agriculture karst, Croatia e-mail: bdorbic@veleknin.hr

\section{Marko Radeljak}

University of Split, University Department of Professional Studies, Croatia

e-mail: marko.radeljak@gmail.com

\section{Exploring the Possibilities of the Application of Spanish Broom and its Products in the Territory of Central Dalmatia}

\begin{abstract}
Spanish broom (Spartium junceum L.) is native to the Mediterranean countries, exclusively in the littoral zone and on the islands. It is currently used in Croatia as an ornamental plant, for the prevention of erosion and in beekeeping. The beginning of the 20th century saw an increase in the demand for Spanish broom as raw material. An intensified production of Spanish broom commenced in 1919 aiming to meet the requirements of textile industry. In 1967 the organised production of Spanish broom ceased, due to the appearance of synthetic fibres that were considerably more affordable. There is big potential for the production of perfume essences, perfumes, soaps and aromatic ointments, to name just a few. Prior to the development of Spanish broom market, it is important to raise public awareness of the importance of this plant and its management. Innovativeness and originality need to be the principal factors in the product branding of Spanish broom, whilst simultaneously respecting its history and tradition. The survey research conducted by pupils and students throughout 2014 provided an insight into mediocre knowledge and awareness of the potential use of Spanish broom in the cities of Split and Šibenik.
\end{abstract}

Key words: Spanish broom, branding, raw materials, industrial plants, landscape. 